\title{
EMPERICAL RELATIONSHIP OF GRAIN YIELD AND DRY MASS OF MAIZE WITH NUTRIENTS SUPPLIED TROUGH SOILS, FERTILIZER AND REMOVED BY CROP
}

\author{
G. VEERANNA \& T. SRIJAYA \\ Regional Agricultural Research Station, Warangal,
}

Professor Jayashankar Telangana State Agricultural University, Hyderabad, Telangana, India

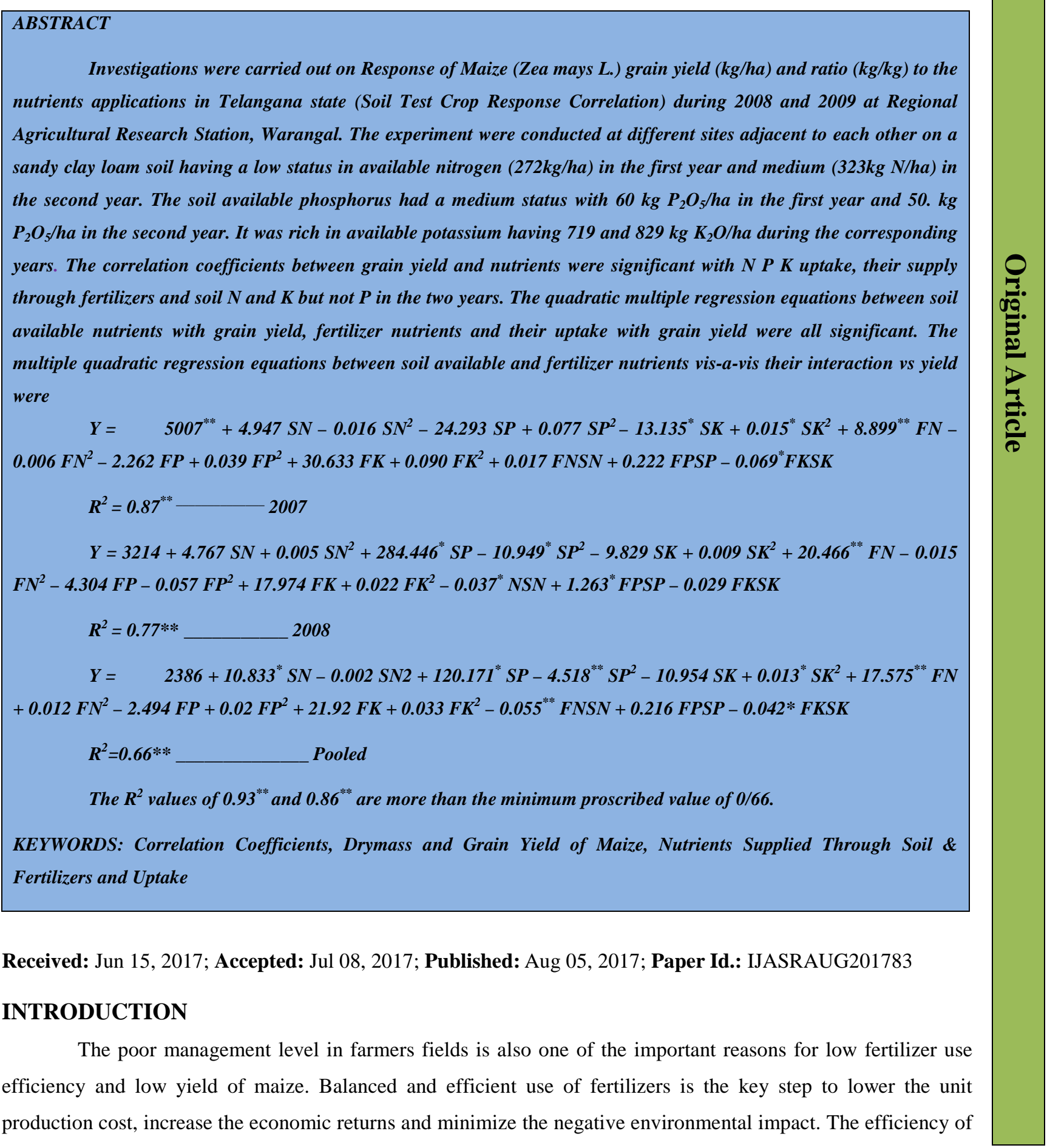


the added fertilizers depends upon many factors like nature of the soil, availability of nutrients, the climate, crop and its variety, management practices used as a promising tool to evaluate the nutrient supplying capacity of the soil and the nutrient requirement of crop. The fertilizer requirement of different crops varies due to their differential production potential, ability to draw the mineralized soil nutrients and their additions through the fertilizers. Farmers in the Central Telangana Zone of Andhra Pradesh seldom follow the recommended dose of 120:60:50 kg/ha. The fertilizer application is indiscriminate. The fertility status of the soil for N P K is highly variable from field to field. Therefore, ad-hoc dose of fertilizer recommendation is not precise for all the fields. The quantitative approach based on the rating of soil available $\mathrm{N}$ $\mathrm{P} \mathrm{K}$ in the low, medium and high categories is also beset with similar limitation.

\section{MATERIALS AND METHODS}

The experiment was conducted at the Regional Agricultural Research Station, Warangal, Telangana State to study Response of Maize (Zea mays L.) grain yield $(\mathrm{kg} / \mathrm{ha})$ and ratio $(\mathrm{kg} / \mathrm{kg})$ to the nutrients applications (Soil Test Crop Response Correlation) during Rabi 2008 and 2009. The experimental site is geographically located at $18^{\circ} 03^{\prime} \mathrm{N}$ latitude and $79^{\circ} 22^{\prime} \mathrm{E}$ longitude at an altitude of $270 \mathrm{~m}$ above the mean sea level. The experiments were conducted at two different sites in the two years adjacent to each other by about $15 \mathrm{~m}$. Composite soil sample was drawn from 0 to $30 \mathrm{~cm}$ depth from different spots moving randomly in a zig zag manner, in the entire field before the commencement of the experiment. It was analyzed for different physico-chemical properties by adopting standard procedures. . The soil was sandy clay loam in texture. It had an alkaline reaction having a pH of 8.10 during 2007 and 8.37 during 2008. There was no problem of salt accumulation in either of the two years. There was a low organic carbon content of 0.47 per cent in the first year and 0.40 per cent in the second year. The fertility status in terms of available nitrogen was different. In the first year, it had a low status with $272.34 \mathrm{~kg} \mathrm{~N} /$ ha while it was medium with $323.67 \mathrm{~kg} \mathrm{~N} /$ ha in the subsequent year. The status of phosphorus was medium with $60 \mathrm{P}_{2} \mathrm{O}_{5} /$ ha in the first year and $50 \mathrm{~kg} \mathrm{P}_{2} \mathrm{O}_{5} / \mathrm{ha}$ in the second year. It was very rich in potassium. The available quantity of $\mathrm{K}_{2} \mathrm{O}$ was $719 \mathrm{~kg} / \mathrm{ha}$ in the first year and $829 \mathrm{~kg} / \mathrm{ha}$ in the second year The main aim of the Soil Test Crop Response experiment was to generate a set of data points with a wide range of values for each controllable variable of fertilizer NPK at different levels of the uncontrollable soil available NPK fertility variables. To achieve this objective, a fertility gradient experiment was conducted. This was to ensure high heterogeneity between the different fertility gradients and homogeneity within each soil fertility gradient for available soil nutrients, management practices adopted and prevailing climatic conditions. The field was divided into three strips. Each strip was $90 \mathrm{~m}$ long and $16 \mathrm{~m}$ wide separated with $1.5 \mathrm{~m}$ wide alley way all along the length. These strips were designated as $\mathrm{O} X, 1 \mathrm{X}$ and $2 \mathrm{X}$ depending upon the quantity of fertilizers added. Fertilizers were not added in the $O X$ gradient. The standard level of $150 \mathrm{~kg} / \mathrm{N} / \mathrm{ha}$ was applied in $1 \mathrm{X}$ strip. Phosphorus application was calibrated to the critical value based on its fixation capacity following Waugh and Fitts (1966). To supply $10 \mathrm{ppm} \mathrm{P}$, a dose of $22.4 \mathrm{~kg} \mathrm{P}_{2} \mathrm{O}_{5}$ /ha was applied to $1 \mathrm{X}$ strip. The potassium application was calibrated to supply $150 \mathrm{~kg}$ exchangeable $\mathrm{K}_{2} \mathrm{O} / \mathrm{ha}$. Since soil available $\mathrm{K}$ status of the soil was high, a minimum dose of 30 $\mathrm{kg} \mathrm{K}_{2} \mathrm{O}$ / ha was applied. The $2 \mathrm{X}$ strip was fertilized with two times the standard dose of nutrients in $1 \mathrm{X}$ gradient. These fertilizer levels are those recommended by the All India Coordinated Research Project on Soil Test Crop Response Correlation Studies.

The exhaust crop of fodder sorghum variety SSG 59-3 was sown during kharif on $1^{\text {st }} \mathrm{July}, 2007$ and $22^{\text {nd }} \mathrm{June}$, 2008. The crop was harvested at flowering stage both years. The fodder yield was recorded from each strip. After the harvest of exhaust crop, the field was ploughed, harrowed and leveled without disturbing the layout demarcation of the 
three strips developed for the fertility gradient experiment. Each strip was divided into 24 plots measuring $7.0 \times 7.8 \mathrm{~m}$. These plots were separated by bunds measuring $45 \mathrm{~cm}$ and alternated by feeder channels of $75 \mathrm{~cm}$ for irrigation

The Treatments Were a Combination of Four Levels of Each N, P and K viz,

$\begin{array}{ccc}\text { Nitrogen (kg N/ha) } & \text { Phosphorus }\left(\mathbf{k g P}_{2} \mathrm{O}_{5} / \mathbf{h a}\right) & \text { Potassium }\left(\mathbf{k g ~ K} \mathbf{K}_{\mathbf{2}} \mathbf{O} / \mathbf{h a}\right) \\ \mathrm{N}_{0}-0 & \mathrm{P}_{0}-0 & \mathrm{~K}_{0}-0 \\ \mathrm{~N}_{1}-80 & \mathrm{P}_{1}-40 & \mathrm{~K}_{1}-40 \\ \mathrm{~N}_{2}-160 & \mathrm{P}_{2}-80 & \mathrm{~K}_{2}-80 \\ \mathrm{~N}_{3}-240 & \mathrm{P}_{3}-120 & \mathrm{~K}_{3}-120\end{array}$

A set of 21 treatments comprising the combined levels of NPK and 3 unfertilized controls were randomly allocated in each fertility gradient strip for soil test crop response experiment in accordance with the recommendation by the All India Coordinated Research Project on soil test crop response correlation studies (www.iasi, res.in). The fertilizers were applied to the plots as per the treatments. One third of nitrogen and full dose of phosphorus and potassium were applied as a basal dose and remaining nitrogen was applied as top dressing at 40 days after sowing and tasseling stage. The crop was irrigated at the time of sowing and remaining six irrigations were given at $25,40,55,70,85$ and 95 days after sowing

\section{Multiple Regression Analysis}

In this approach yield is regressed with soil nutrients, fertilizer nutrients, their quadric terms and the interaction term of soil and fertilizer nutrients.

The multiple regression equation is

$$
\begin{aligned}
& \mathrm{Y}=\mathrm{A}+\mathrm{b}_{1} \mathrm{SN}+\mathrm{b}_{2} \mathrm{SN}^{2}+\mathrm{b}_{3} \mathrm{SP}+\mathrm{b}_{4} \mathrm{SP}^{2}+\mathrm{b}_{5} \mathrm{SK}+\mathrm{b}_{6} \mathrm{SK}^{2}+\mathrm{b}_{7} \mathrm{FN}+\mathrm{b}_{8} \mathrm{FN}^{2}+\mathrm{b}_{9} \mathrm{FP} \\
& +\mathrm{b}_{10} \mathrm{FP}^{2}+\mathrm{b}_{11} \mathrm{FK}+\mathrm{b}_{12} \mathrm{FK}^{2}+\mathrm{b}_{13} \mathrm{FNSN}+\mathrm{b}_{14} \mathrm{FPSP}+\mathrm{b}_{15} \mathrm{FKSK}
\end{aligned}
$$

Where

$$
\begin{array}{lll}
\mathrm{Y} & = & \text { Crop yield }(\mathrm{kg} / \mathrm{ha}) \\
\mathrm{A} & = & \text { Intercept }(\mathrm{kg} / \mathrm{ha}) \\
\mathrm{b}_{\mathrm{I}} & = & \text { Regression coefficients }(\mathrm{kg} / \mathrm{kg}) \\
\mathrm{SN}, \mathrm{SP} \text { and SK } & = & \text { Available soil nitrogen, soil phosphorus and soil Potassium }(\mathrm{kg} / \mathrm{ha}) \text { respectively. } \\
\mathrm{FN}, \mathrm{FP} \text { and FK } & = & \text { Fertilizer nitrogen, fertilizer phosphorus and fertilizer potassium }(\mathrm{kg} / \mathrm{ha}) \text { respectively. }
\end{array}
$$

\section{RESULTS AND DISCUSSIONS}

The grain yield was positively and significantly correlated with N P K applied through the fertilizers and their uptake by the crop both during 2008 and 2009. The pooled estimates were also similar. Soil N and K also established a significant and positive correlation with grain yield. But the association of soil phosphorus was feasible. The dry mass accumulation was also positive and significantly influenced by the N P K application, through the fertilizers and their 
uptake by the plants, during the two years and also on pooled basis of the soil $\mathrm{N}$ and $\mathrm{K}$ in first year while, $\mathrm{P}$ and $\mathrm{K}$ in the second year did not establish a significant correlation, with dry mass accumulation.

The pooled correlation coefficient for dry mass vs soil available $\mathrm{K}$ was not significant. The correlation matrix showed that there was strong association of soil available nitrogen with N P or K applied through the fertilizers in the first year and on pooled basis but not in the second year.

The soil available $\mathrm{P}$ correlated with fertilizer $\mathrm{N}$ only in the first year. It did not establish a significant association with N P or K supplied through fertilizers in the second year and pooled basis. The correlation coefficients for soil available potassium with N P K through fertilizers were positive and significant in the first year and over the pooled estimates. Its association was feable with fertilizer nitrogen only in the second year. The uptake of N P K established positive and highly significant correlation with fertilizer N P K both during 2008 and 2009as well as in the pooled estimates.

\section{Multiple Regression Equations}

\section{Influence of Soil Nutrients on Grain Yield of Maize}

The relationship of soil available N P K with grain yield of maize was best fitted to the following quadratic regression models.

$$
\begin{aligned}
& \mathrm{Y}=-1989+40.91^{* *} \mathrm{SN}-0.065^{* *} \mathrm{SN}^{2}+47.32 \mathrm{SP}-1.59 \mathrm{SP}^{2} \\
& -0.43 \mathrm{SK}+0.001 \mathrm{SK}^{2}--------\mathrm{R}^{2}=0.49^{* *}-2008 \\
& \mathrm{Y}=-2497-2.92 \mathrm{SN}+0.012 \mathrm{SN}^{2}+401.34^{*} \mathrm{SP}-14.40^{*} \mathrm{SP}^{2} \\
& +14.01 \mathrm{SK}-0.009 \mathrm{SK}^{2}-----------\mathrm{R}^{2}=0.21^{*}-2009 \\
& \mathrm{Y}=-1628+19.464^{* *} \mathrm{SN}-0.028^{*} \mathrm{SN}^{2}+93.395 \mathrm{SP}-3.507 \mathrm{SP}^{2} \\
& +5.221 \mathrm{SK}+0.001 \mathrm{SK}^{2}------\mathrm{R}^{2}=0.28^{* *} \longrightarrow \text { Pooled }
\end{aligned}
$$

The coefficients of determination were significant for the regression models. The linear and quadratic coefficients were significant for soil nitrogen in 2008 and on the basis of the joint regression model over the two years. The linear and quadratic regression coefficients were significant for soil phosphorus in the second year.

\section{Influence of Fertilizer Nutrients on Grain Yield of Maize}

The multiple regression equations best fitted to the quadratic model were

$$
\begin{aligned}
& \mathrm{Y}=2402^{* *}+10.193^{* *} \mathrm{FN}+0.001 \mathrm{FN}^{2}-0.446 \mathrm{FP}+0.049 \mathrm{FP}^{2} \\
& -3.103 \mathrm{FK}+0.031 \mathrm{FK}^{2}------\mathrm{R}^{2}=0.86^{* *} \longrightarrow 2008 \\
& \mathrm{Y}=3461^{* *}+14.67^{* *} \mathrm{FN}-0.029^{*} \mathrm{FN}^{2}+15.69^{*} \mathrm{FP}-0.079 \mathrm{FP}^{2} \\
& -1.53 \mathrm{FK}+0.02 \mathrm{FK}^{2}--------\mathrm{R}^{2}=0.62^{* *} \longrightarrow 2009 \\
& \mathrm{Y}=2932^{* *}+12.43^{* *} \mathrm{FN}-0.014 \mathrm{FN}^{2}+7.62 \mathrm{FP}-0.015 \mathrm{FP}^{2} \\
& -2.32 \mathrm{FK}+0.026 \mathrm{FK}^{2}--------\mathrm{R}^{2}=0.54^{* *} \longrightarrow \text { Pooled }
\end{aligned}
$$

The coefficients of determination were highly significant and larger than those for the relationship of soil nutrients 
with yield. The linear regression coefficient was highly significant during 2008 and in the joint regression model for the two years. In the second year, both linear and quadratic regression coefficients were significant for fertilizer nitrogen.

\section{Influence of Soil and Fertilizer Nutrients on Grain Yield of Maize}

The regression models to study the relative contribution of soil available and applied fertilizer nutrients on grain yield of maize were

$$
\begin{aligned}
& \mathrm{Y}=2543^{* *}-0.614 \mathrm{SN}-3.681 \mathrm{SP}-0.021 \mathrm{SK}+10.739^{* *} \mathrm{FN} \\
& +0.001 \mathrm{FN}^{2}+0.269 \mathrm{FP}+0.045 \mathrm{FP}^{2}-3.834 \mathrm{FK}+0.037 \mathrm{FK}^{2} \\
& \mathrm{R}^{2}=0.86^{* *}-2008 \\
& \mathrm{Y}=2354^{* *}+1.299 \mathrm{SN}+73.287^{* *} \mathrm{SP}-0.032 \mathrm{SK}+14.223^{* *} \mathrm{FN} \\
& -0.024^{* *} \mathrm{FN}^{2}+13.41 \mathrm{FP}-0.074 \mathrm{FP}^{2}+2.057 \mathrm{FK}-0.006 \mathrm{FK}^{2} \\
& \mathrm{R}^{2}=0.69^{* *}-2009 \\
& \mathrm{Y}=1355^{* *}+1.145 \mathrm{SN}-16.498 \mathrm{SP}+2.709^{* *} \mathrm{SK}+11.38^{* *} \mathrm{FN} \\
& -0.011 \mathrm{FN}^{2}+6.282 \mathrm{FP}-0.012 \mathrm{FP}^{2}-3.482 \mathrm{FK}+0.016 \mathrm{FK}^{2} \\
& \mathrm{R}^{2}=0.60^{* *} \longrightarrow \text { Pooled }
\end{aligned}
$$

The coefficients of determination were highly significant for the three models. The linear regression model was highly significant for fertilizer nitrogen in the first year. The linear regression coefficient for soil phosphorus and both linear and quadratic terms for fertilizer nitrogen were highly significant in the second year. The pooled estimate recorded highly significant contribution of the linear components for soil potassium and fertilizer nitrogen.

\section{Influence of Nutrient Uptake and Grain Yield of Maize}

The multiple regression equations for the dependence of grain yield of maize on uptake of nutrients were

$$
\begin{aligned}
& \mathrm{Y}=604^{* *}+21.136^{* *} \mathrm{UN}+68.385^{* *} \mathrm{UP}+20.741^{*} \mathrm{UK} \\
& \mathrm{R} 2=0.93^{* * *}-2007 \\
& \mathrm{Y}=976^{* *}+17.104^{* *} \mathrm{UN}+47.504^{* *} \mathrm{UP}+54.135^{* *} \mathrm{UK} \\
& \mathrm{R} 2=0.86^{* *}-2008 \\
& \mathrm{Y}=708^{* *}+20.411^{* *} \mathrm{UN}+51.001^{* *} \mathrm{UP}+43.738^{* *} \mathrm{UK} \\
& \mathrm{R} 2=0.91^{* *} \text { Pooled }
\end{aligned}
$$

The coefficients of determination were highly significant for the three equations. The regression coefficients for the uptake of nitrogen, phosphorus and potassium were significant to predict the variation in grain yield of maize during 2007 and 2008 as well as on the pooled basis.

\section{Influence of Soil and Fertilizer Nutrients on Their Uptake by Maize}


The mathematical equations describing the relative contribution of soil and fertilizer nutrients on their uptake were estimated as.

\section{Uptake of Nitrogen}

$$
\begin{aligned}
& \mathrm{UN}=41.25^{* *}-0.05 \mathrm{SN}+0.342^{* *} \mathrm{FN} \\
& \mathrm{R}^{2}=0.78^{* *}-2008 \\
& \mathrm{UN}=74.59^{* *}+0.025 \mathrm{SN}+0.231^{* *} \mathrm{FN} \\
& \mathrm{R}^{2}=0.42^{* *}-2009 \\
& \mathrm{UN}=53.68^{* *}+0.017 \mathrm{SN}+0.269^{* *} \mathrm{FN} \\
& \mathrm{R}^{2}=0.44^{* *}-\text { Pooled }
\end{aligned}
$$

\section{Uptake of Phosphorus}

$$
\begin{aligned}
& \mathrm{UP}=15.48^{* *}+0.089 \mathrm{SP}+0.078^{* *} \mathrm{FP} \\
& \mathrm{R}^{2}=0.34^{* *}-2008 \\
& \mathrm{UP}=17.10^{* *}+0.187 \mathrm{SP}+0.074^{* *} \mathrm{FP} \\
& \mathrm{R}^{2}=0.21^{* *}-2009 \\
& \mathrm{UP}=17.51^{* *}+0.031 \mathrm{SP}+0.077^{* *} \mathrm{FP} \\
& \mathrm{R}^{2}=0.25^{* *} \stackrel{\text { Pooled }}{ }
\end{aligned}
$$

\section{Uptake of Potassium}

$$
\begin{aligned}
& \mathrm{UK}=13.05^{* *}+0.001 \mathrm{SK}+0.059^{* *} \mathrm{FK} \\
& \mathrm{R}^{2}=0.16^{* *}-2008 \\
& \mathrm{UK}=15.49^{* *}+0.005 \mathrm{SK}+0.081^{* *} \mathrm{FK} \\
& \mathrm{R}^{2}=0.30^{* *}-2009 \\
& \mathrm{UK}=6.27+0.017^{* *} \mathrm{SK}+0.054^{* *} \mathrm{FK} \\
& \mathrm{R}^{2}=0.22^{* *} \longrightarrow \text { Pooled }
\end{aligned}
$$

The coefficients of determination were highly significant for all the equations. The regression coefficients were also highly significant for N P K applied through the fertilizers and not those supplied through the soil on their uptake by the crop.

\section{Influence of Nutrients Applied Through the Fertilizers, Supplied by the Soil and Their Interaction}

The quadratic multiple regression equations explaining the relative role of $\mathrm{N} \mathrm{P} \mathrm{K}$ available through fertilizers and soils and their interactions on grain yield of maize were.

$$
\mathrm{Y}=5007^{* *}+4.947 \mathrm{SN}-0.016 \mathrm{SN}^{2}-24.293 \mathrm{SP}+0.077 \mathrm{SP}^{2}
$$




$$
\begin{aligned}
& -13.135^{*} \mathrm{SK}+0.015^{*} \mathrm{SK}^{2}+8.899^{* *} \mathrm{FN}-0.006 \mathrm{FN}^{2} \\
& -2.262 \mathrm{FP}+0.039 \mathrm{FP}^{2}+30.633 \mathrm{FK}+0.090 \mathrm{FK}^{2}+0.017 \mathrm{FNSN} \\
& +0.222 \mathrm{FPSP}-0.069^{*} \mathrm{FKSK}------\mathrm{R}^{2}=0.87^{* *}-2008 \\
& \mathrm{Y}=3214+4.767 \mathrm{SN}+0.005 \mathrm{SN}^{2}+284.446^{*} \mathrm{SP}-10.949^{*} \mathrm{SP}^{2} \\
& -9.829 \mathrm{SK}+0.009 \mathrm{SK}^{2}+20.466^{* *} \mathrm{FN}-0.015 \mathrm{FN}^{2}-4.304 \mathrm{FP} \\
& -0.057 \mathrm{FP}^{2}+17.974 \mathrm{FK}+0.022 \mathrm{FK}^{2}-0.037^{*} \mathrm{FNSN} \\
& +1.263^{*} \mathrm{FPSP}-0.029 \mathrm{FKSK}----\mathrm{R}^{2}=0.77^{* *}-2009 \\
& \mathrm{Y}=2386+10.833^{*} \mathrm{SN}-0.002 \mathrm{SN}^{2}+120.171^{*} \mathrm{SP}-4.518^{* *} \mathrm{SP}{ }^{2} \\
& -10.954 \mathrm{SK}+0.013^{*} \mathrm{SK}{ }^{2}+17.575^{* *} \mathrm{FN}+0.012 \mathrm{FN}^{2}-2.494 \mathrm{FP} \\
& +0.02 \mathrm{FP}^{2}+21.92 \mathrm{FK}^{2} 0.033 \mathrm{FK}^{2}-0.055^{* *} \mathrm{FNSN} \\
& +0.216 \mathrm{FPSP}-0.042^{*} \mathrm{FKSK}----\mathrm{R}^{2}=0.66^{* *}-\mathrm{Pooled}
\end{aligned}
$$

The regression models to predict the grain yield of maize through the soil and fertilizer nutrients vis-à-vis their interaction had highly significant coefficients of determination of 0.87 in the first year and 0.77 in the second year. The coefficient of determination for the pooled equation was also highly significant with the value of 0.66. The linear regression coefficient was highly significant for fertilizer nitrogen in the first year. The linear quadratic coefficient for the soil available $\mathrm{K}$ and the interaction between soil available and fertilizer $\mathrm{K}$ were also significant. In the second year, the linear and quadratic coefficients were significant for soil phosphorus and its interaction with fertilizer phosphorus. The linear regression coefficient for fertilizer nitrogen and its interaction with soil nitrogen was also significant. The pooled regression equation showed significant linear regression coefficient for soil nitrogen. The linear and quadratic coefficients were significant for soil potassium and the linear regression coefficient was significant for fertilizer nitrogen as well as its interaction with soil nitrogen. The signs for linear, quadratic and interaction regression coefficients were +-- for fertilizer nitrogen.

The association of crop yield with N P K available in the soil supplied by fertilizers and their uptake by maize form the basis for soil test crop correlation studies. The present investigation established that the maize yield was influenced by these nutrients. The correlation coefficients were significant for all the test variables except the feeble correlation of soil available phosphorus during 2007, 2008 and as a mean response over the two years. Ghosh and Singh (2002) studied the association of soil available $\mathrm{P}$ with the grain yield of maize. They observed that the soil available $\mathrm{P}$ extracted by Olsen and Bray and Kurtz - I method was not correlated with yield. Its extraction by Nelsons method was most effective with a highly significant correlation of 0.89 , while that extracted by Hunter had a significant correlation coefficient of 0.48 . These results explain that the influence of phosphorus on grain yield was dependent on the method of its extraction. The soil available P in the present investigation was also extracted by Olsen's method Hence N P K supplied through fertilizers and $\mathrm{N}$ and $\mathrm{K}$ from soil available pool had a significant contribution in enhancing the nutrient uptake and in turn the crop yield.

In view of the significant correction coefficients so obtained, the nutrient values were regressed with the crop yield. The multiple regression equations of the quadratic form were best fitted. The linear and quadratic coefficients of soil 
nitrogen were highly significant for soil available nitrogen in 2008 and also in the pooled estimate of the equation over the two years. In the second year, the linear and quadratic coefficients were significant for phosphorus. The soil had less quantity of available $\mathrm{N}$ in the first than in the second year. The available phosphorus content was more in the first than in the second year. The significant contribution of the two nutrients coincided with low level of their availability. The significant contribution of nitrogen in the first year and phosphorus in the second year indicates that the relatively low level of availability in the soil was perhaps due indirectly to better utilization of these nutrients applied through fertilizers. Prasad (1994) observed that the alkaline $\mathrm{K} \mathrm{MnO}_{4}$ extracted nitrogen, Olsen's - $\mathrm{P}$ and $\mathrm{NH}_{4} \mathrm{OAc}-\mathrm{K}$ recorded significant partial regression coefficients on yield of maize through the linear multiple regression equation from soil samples of artificially created fertility gradients in the soil.

The multiple regression equation to estimate the relative role of fertilizer nutrients were more dependable to predict the yield variability owing to highly significant $\mathrm{R}^{2}=0.86$ in $2007,0.62$ in 2008 and 0.54 as a mean over the two years compared to the $\mathrm{R}^{2}$ of $0.49,0.21$ and 0.28 for the soil available nutrients. The linear regression coefficient was highly significant for nitrogen in the first year. This indicate that the yield response was proportionate with increase in the level of this nutrient up to $240 \mathrm{~kg} \mathrm{~N} / \mathrm{ha}$ because of the low level of soil available $\mathrm{N}$ than in the second year. The quadratic regression coefficient was positive. Hence, it is evident that this soil needs more nitrogen to further increase the level of crop production. Conversely, in the second year, the quadratic regression was significant with a "- "sign and a highly significant positive linear regression coefficient. This result indicates that the relatively $\mathrm{N}$ enriched soil tend to reduce the rate of improvement in the grain yield beyond the linear response for optimum production.

The relative efficiency of yield estimation in maize through uptake of $\mathrm{N}, \mathrm{P}$ and $\mathrm{K}$ was more efficient than through the fertilizer and soil also emphasized that the crop yield is more precisely dependent on the absorption and accumulation of nutrients in the plant tissue than those available in the soil and supplied through fertilizers which undergo several interactions in the rhizosphere and hence they are less dependable to relate their efficiency in yield prediction. The $\mathrm{R}^{2}$ values for the linear multiple regression equation were highly significant with estimated values of 0.93 in the first year, 0.86 in the second year 0.91 as mean over the two year. The linear regression coefficients each of $\mathrm{N}, \mathrm{P}$ and $\mathrm{K}$ were significant during both the years. These trends confirm that a definite quantity of nutrients accumulated in the plant tissue has a significant bearing on crop yield. Velayutham et al, (1985) reported that the soil test crop response correlation for economic yield of crops is possible only when the response to applied nutrients follow the law of diminishing returns. Out of the eight different response types in this multiple regression equation the signs for the linear and quadratic terms of the added fertilizer and the interaction between the fertilizer and soil test values viz, (1) - - + (2) - - - (3) + + + (4) + + - (5) - + $+(6)-+-(7)+-+(8)+--$, the last alone is ideal for derivation of soil test based fertilizer recommendation.

The linear multiple regression equation showed that the regression coefficients were significant for N, P and K applied through the fertilizer but not those available in the soil during the two years. This indicates that the relative contribution of nutrients through the fertilizers is relatively more than those available in the soil to influence the grain production.

The multiple regression equation to predict the yield of maize by conjoint influence of N P K available in the soil and those applied through the fertilizers vis-a-vis their interactions recorded very high and significant $\mathrm{R}^{2}$ values of 0.87 in the first year and 0.77 in the second year. Hence they satisfied the fundamental requirement of $\nless$ the $R^{2}$ value of 0.66 laid down by Ramamoorthy et al, (1967) for the success of an STCR experiment to draw valid inferences. The equations in 
both the years established the law of diminishing returns through the + - - signs for the linear and quadratic regressions of fertilizer nitrogen and its interaction with soil nitrogen during both the years. This observation is similar to that reported by Truog (1960) although Ramamoorthy (1967) claimed that, the law of diminishing returns equally operate even for the relatively immobile and less mobile $\mathrm{P}$ and $\mathrm{K}$ nutrients.

\section{REFERENCES}

1. Ghosh B N and Singh R D 2002. Suitability of soil test methods for available phosphorus and its critical levels for maize in acid soils of Uttaranchal Hills. Journal of the India society of soil science, vol. 50 pp $132-134$.

2. Prasad R 1994 .Evaluation of methods for available N, P and $K$ for rice and maize under field condition in Inceptisol. Journal of the Indian society of soil science, Vol. 42, No. 2, pp 318-320.

3. Ramamoorthy B, Narasimhan R L and Dinesh $R S$ 1967. Fertilizer application for specific yield targets of Sonara-64. Indian Farming $5: 43-45$.

4. Troug E 1960 Fifty years of soil testing, transactions of $7^{\text {th }}$ International Congress of Soil Science. Vol. III, Commission IV.PaperNo.746-53.

5. Velayutham M, Reddy K C K and Sankar G R M 1985 All India Coordinated Research Project on Soil Test Crop Response Correlation and its impact on agricultural production. Fertilizer news. April pp 81-98.

Table 1: Correlation Coefficients between Dry Mass and Grain Yield of Maize with Nutrients Supplied Through Soil Fertilizers and Their Uptake by the Crop during Rabi 2008

\begin{tabular}{|c|c|c|c|c|c|c|c|c|c|c|}
\hline & FP & FK & SN & SP & SK & UN & UP & UK & GY & DMY \\
\hline FN & $.582^{* * *}$ & $.449^{* * *}$ & $.630^{* * *}$ & $.239^{*}$ & $.280^{*}$ & $.880^{* * *}$ & $.801^{* * *}$ & $.676^{* * *}$ & $.904^{* * *}$ & $.357^{* * *}$ \\
\hline FP & & $.545^{* *}$ & $.433^{* *}$ & .212 & $.331^{* * *}$ & $.632^{* * *}$ & $.579^{* * *}$ & $.435^{* * *}$ & $.666^{* * *}$ & $.400^{* * *}$ \\
\hline FK & & & $.271^{*}$ & .135 & $.498^{* * *}$ & $.454^{* * *}$ & $.398^{* * *}$ & $.402^{\text {*** }}$ & $.478^{* * *}$ & $.409^{* * *}$ \\
\hline SN & & & & $.281^{*}$ & $.332^{* * *}$ & $.484^{* * *}$ & $.528^{* * *}$ & $.239^{*}$ & $.558^{* * *}$ & .094 \\
\hline SP & & & & & .000 & .223 & .214 & .196 & .199 & $.297^{*}$ \\
\hline SK & & & & & & $.355^{* *}$ & $.303^{* *}$ & .211 & $.305^{* * *}$ & .154 \\
\hline UN & & & & & & & $.844^{* * *}$ & $.754^{* * *}$ & $.944^{* * *}$ & $.452^{* * *}$ \\
\hline UP & & & & & & & & $.650^{* * *}$ & $.896^{* * *}$ & $.520^{* * *}$ \\
\hline UK & & & & & & & & & $.762^{* * *}$ & $.548^{* * *}$ \\
\hline
\end{tabular}

$*$ and $* *$ indicate significance at 5 and $1 \%$ level respectively

Table 2: Correlation Coefficients between Dry Mass and Grain Yield of Maize with Nutrients Supplied Through Soil Fertilizers and Their Uptake by the Crop During Rabi 2009

\begin{tabular}{|l|c|c|c|c|c|c|c|c|c|c|}
\hline & FP & FK & SN & SP & SK & UN & UP & UK & GY & DMY \\
\hline FN & $.582^{* *}$ & $.449^{* *}$ & .174 & -.183 & .166 & $.646^{* *}$ & $.502^{* *}$ & $.654^{* *}$ & $.725^{* *}$ & $.327^{* *}$ \\
\hline FP & & $.545^{* *}$ & .181 & .012 & $.331^{* *}$ & $.561^{* *}$ & $.441^{* *}$ & $.594^{* *}$ & $.587^{* *}$ & $.272^{*}$ \\
\hline FK & & & .090 & -.043 & $.381^{* *}$ & $.422^{* *}$ & $.433^{* *}$ & $.539^{* *}$ & $.454^{* *}$ & $.260^{*}$ \\
\hline SN & & & & .150 & .063 & .168 & .212 & .209 & $.243^{*}$ & $.395^{* *}$ \\
\hline SP & & & & & -.042 & .126 & .111 & .145 & .166 & .185 \\
\hline SK & & & & & $.258^{* *}$ & $.263^{*}$ & $.274^{*}$ & $.258^{*}$ & .173 \\
\hline UN & & & & & & $.581^{* *}$ & $.673^{* *}$ & $.844^{* *}$ & $.458^{* *}$ \\
\hline UP & & & & & & & $.607^{* *}$ & $.747^{* *}$ & $.515^{* *}$ \\
\hline UK
\end{tabular}


Table 3: Correlation Coefficients between Dry Mass and Grain Yield of Maize with Nutrients Supplied Through Soil Fertilizers and Their Uptake by the Crop Pooled of 2008 and 2009

\begin{tabular}{|l|c|c|c|c|c|c|c|c|c|c|}
\hline & FP & FK & SN & SP & SK & UN & UP & UK & GY & DMY \\
\hline FN & $.582^{* *}$ & $.449^{* *}$ & $.399^{* *}$ & .069 & $.208^{* *}$ & $.662^{* *}$ & $.625^{* *}$ & $.575^{* *}$ & $.711^{* *}$ & $.317^{* *}$ \\
\hline FP & & $.545^{* *}$ & $.306^{* *}$ & .123 & $.309^{* *}$ & $.518^{* *}$ & $.494^{* *}$ & $.447^{* *}$ & $.547^{* *}$ & $.303^{* *}$ \\
\hline FK & & & $.179^{*}$ & .060 & $.410^{* *}$ & $.381^{* *}$ & $.409^{* *}$ & $.409^{* *}$ & $.407^{* *}$ & $.301^{* *}$ \\
\hline SN & & & & $.199^{*}$ & $.192^{* *}$ & $.294^{* *}$ & $.351^{* *}$ & $.206^{*}$ & $.362^{* *}$ & $.246^{* *}$ \\
\hline SP & & & & & -.142 & -.030 & .087 & -.042 & -.026 & $.313^{* *}$ \\
\hline SK & & & & & & $.426^{* *}$ & $.319^{* *}$ & $.377^{* *}$ & $.404^{* *}$ & .030 \\
\hline UN & & & & & & & $.681^{* *}$ & $.783^{* *}$ & $.919^{* *}$ & $.213^{*}$ \\
\hline UP & & & & & & & & $.618^{* *}$ & $.781^{* *}$ & $.426^{* *}$ \\
\hline UK & & & & & & & & & $.833^{* *}$ & $.231^{* *}$ \\
\hline
\end{tabular}

$*$ and $* *$ indicate significance at 5 and $1 \%$ level respectively 